\title{
PRIMARY SOLITARY PLASMACYTOMA INVOLVING THE ILIUM BONE IN A PREGNANT WOMAN
}

\author{
Kesler M.S.
}

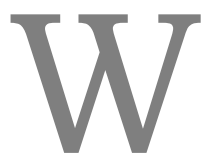

e describe such a case in a woman at the 19th week of pregnancy, who presented with pain in the left pelvis. MRI of the pelvis demonstrated a large mass with a pathological fracture involving the left ilium. Histopathology demonstrated plasma cell neoplasm. No evidence for additional foci on whole-body MRI and bone marrow aspiration. This was consistent with solitary plasmacytoma of the bone. She was treated with dexamethasone and then underwent an elective Cesarean section at 36 weeks. After delivery, PET/CT with FDG was ordered which showed increased uptake in the tumor involving the left ilium, without additional pathological foci.

Keywords: positron emission tomography, plasmacytoma, pregnant, ilium.

Corresponding author: Kesler M.S., e-mail: mkezzler@gmail.com

For citation: Kesler M.S. Primary solitary plasmacytoma involving the ilium bone in a pregnant woman. REJR 2019; 9(1):284-287. DOI:10.21569/2222-7415-2019-9-1-284-287.

Статья получена: $\quad 29.01 .19 \quad$ Статья принята: $\quad \begin{aligned} & 14.02 .19\end{aligned}$

\section{САУЧАЙ ПЕРВИЧНОЙ СОАИТАРНОЙ ПААЗМОЦИТОМЫ С ВОВАЕЧЕНИЕМ ПОАВЗАОШНОЙ КОСТИ У БЕРЕМЕННОЙ ЖЕНЩИНЫ}

\author{
Kecıер M.C.
}

Медицинский центр Тель-Авив Сураски. г. Тель-Авив, Израиль.

ель. Представить разбор случая солитарной плазмоцитомы у женщины на 19ой неделе беременности с болями в области таза слева.

Материалы и методы. Проведенная МРТ таза выявима опухолевую массу $е$ вой подвздошной кости с патологическим переломом. При биопсии: опухоль, состоящая из плазматических клеток. При последующей МРТ всего тела и в аспирате костного мозга не выявлено дополнительных очагов, указывающих на множественную миелому. $\Lambda$ ечение дексаметазоном проводимось до кесарева сечения (на 36-ой неделе беременности). Проведенная после операции ПЭТ/КТ всего тела также не показала дополнительных очагов накопцения F-18-Фтордезоксиглюкозы, что подтвердило первоначальный диагноз солитарной плазмоцитомы.

КАючевые слова: позитронно-эмиссионная томография, плазмоцитома, беременность, подвздошная кость.

Контактный автор: Кеслер M.C., e-mail: mkezzler@gmail.com

Для иитирования: Кеслер М.С. Случай первичной солитарной плазмоиитомы с вовлечением подвздошной кости у беременной женшины. REJR 2019; 9(1):284-287. DOI:10.21569/2222-7415-2019-9-1-284-287.

Received: $\quad 29.01 .19 \quad$ Accepted: 14.02 .19 
I

ntroduction.

Solitary plasmacytoma (SP) is a rare malignant tumor of plasma cells with no evidence of systemic proliferation. When there is systemic involvement, that is, the involvement of multiple skeletal sites, the disease is called multiple myeloma (MM), one of the most frequent presentations of neoplasia of the plasma cells.

The SP presents an incidence of 5-8\% of plasma cell malignancies and two subtypes: extramedullary solitary plasmacytoma (ESP) and solitary bone plasmacytoma (SBP). ESP originates from soft tissues and is more frequent in the head and neck region, specifically in the upper respiratory tract, whereas the SBP presents as an intramedullary bone lesion in the axial skeleton or pelvic bones [1, 2].

SP and MM typically affects older patients with a median age at diagnosis of 67-70 years and only $3 \%$ of cases are diagnosed before the age of 40. Moreover, SP and MM is more common in men. Therefore, pregnancy rarely occurs in pa-

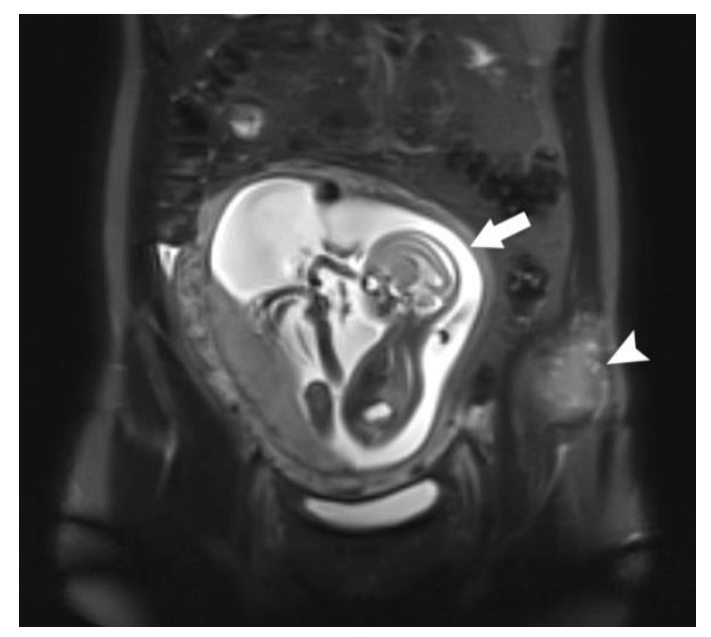

Fig. 1 (Рис. 1)

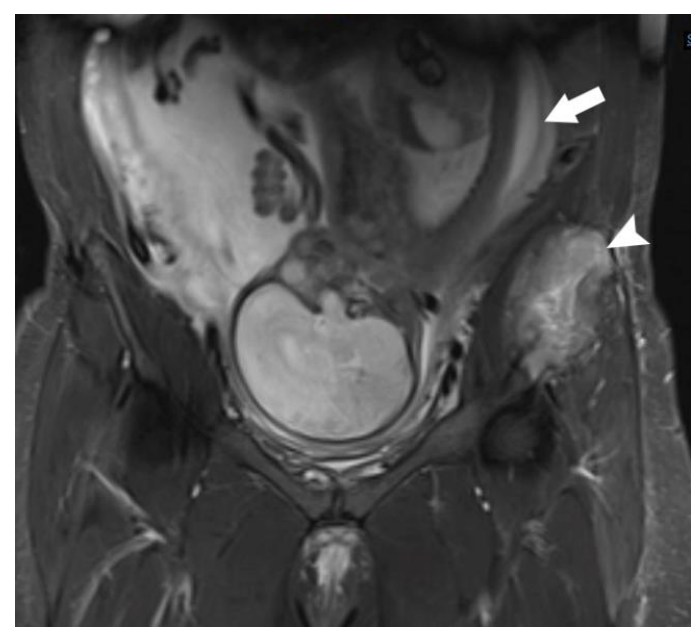

Fig. 2 (Рис. 2)
Fig. 1. MRI.

The T2-weighted coronal image shows gravid uterus with 22 weeks old fetus (arrow) and pathological mass on the left ilium (arrowhead).

Рис. 1. MPT.

Т2-взвешенное изображение, корональная плоскость; показана матка с 22- недельным плодом (стрелка) и патологическая масса в мевой подвздошной кости (головка стрелки).
Fig. 2. MRI.

The T2-weighted coronal image shows gravid uterus with 34 weeks old fetus (arrow) and pathological mass on the left ilium (arrowhead).

Pис. 2. MPT.

Т2-взвешенное изображение, корональная плоскость; показана матка с 34-недельным плодом (стрелка) и патологическая масса в мевой подвздошной кости (головка стрелки).

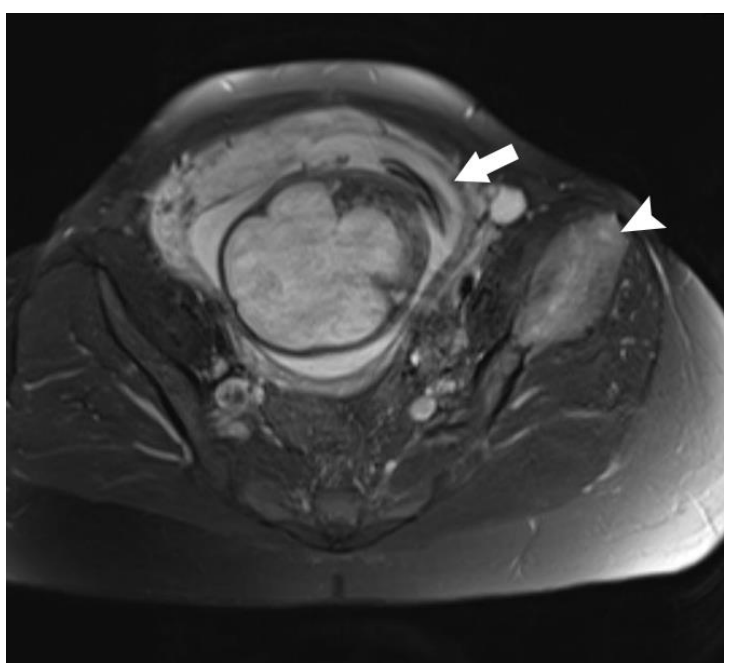

\section{Fig. 3. MRI.}

The T2-weighted axial image shows gravid uterus with 34 weeks old fetus (arrow) and pathological mass on the left ilium (arrowhead).

\section{Рис. 3. MPT.}

Т2-взвешенное изображение, аксиальная плоскость; показана матка с 34-недельным плодом (стрелка) и патологическая масса в мевой подвздошной кости (головка стрелки).

Fig. 3 (Рис. 3) 


\section{RUSSIAN ELECTRONIC JOURNAL OF RADIOLOGY}

tients with MM and only 42 cases of MM [3] and 1 case of ESP [4] in pregnancy have been reported in the literature. Herein - we report an additional case of SBP.

\section{Case Report.}

A 35-year-old pregnant woman, in the 19th week of pregnancy, presented with severe pain in the pelvis. Magnetic resonance imaging (MRI) demonstrated a large mass $(7 \times 10 \mathrm{~cm})$ with a pathological fracture involving the left ilium. A mass biopsy was performed. Histopathology demonstrated plasma cell neoplasm, positive to CD138, CD79a, CD56. The bone marrow aspiration without plasma cell infiltration. On wholebody MRI, no data for additional foci. This was consistent with solitary plasmacytoma of the left ilium.

She was treated with dexamethasone $40 \mathrm{mg}$ daily for four days each week. She then underwent an elective Cesarean section at 36 weeks delivering a normal healthy male infant. After delivery, on positron emission tomography/computed tomography scans (PET/CT) with 18fluorinefluorodeoxyglucose (FDG) was ordered which showed increased uptake in tumor involving the left ilium, without additional pathological uptake.

The patient was treated with radiation therapy to the left pelvis and by protocol VTD (Bortezomib, Thalidomide, Dexamethasone) achieving partial response after 5 cycles of therapy. She went on to autologous peripheral blood stem cell transplant 6 months post delivery.

\section{Discussion.}

Cancer is diagnosed in approximately one out of 1000 pregnant women and this incidence is expected to grow due to the rising median age at pregnancy. The most common cancers associated with pregnancy are cervical (1.2:10000 pregnancies), breast cancer (1:3000-10000), melanoma (2.6:1000), lymphomas (1:1000-6000) and leukemias (1:75000-100000). Hematologic malignancies, which are considered to be diseases of old age, such as multiple myeloma (MM) and myeloproliferative neoplasms (MPNs), are recently more commonly encountered while the patients are pregnant owing to the rising median age at pregnancy, improved diagnostic molecular techniques used in MPNs and better overall survival in MM [5].

The diagnosis MM may be problematic in this context as some of the symptoms and signs, such as back pain and anemia, can be attributed to pregnancy [3]. SBP is a little easier to diagnose. Physical findings are related to the site of involvement, presenting as a painful mass, pathologic fracture, or root or spinal cord compression syndrome [2]. Furthermore, if the patient wishes to continue her pregnancy, therapeutic options

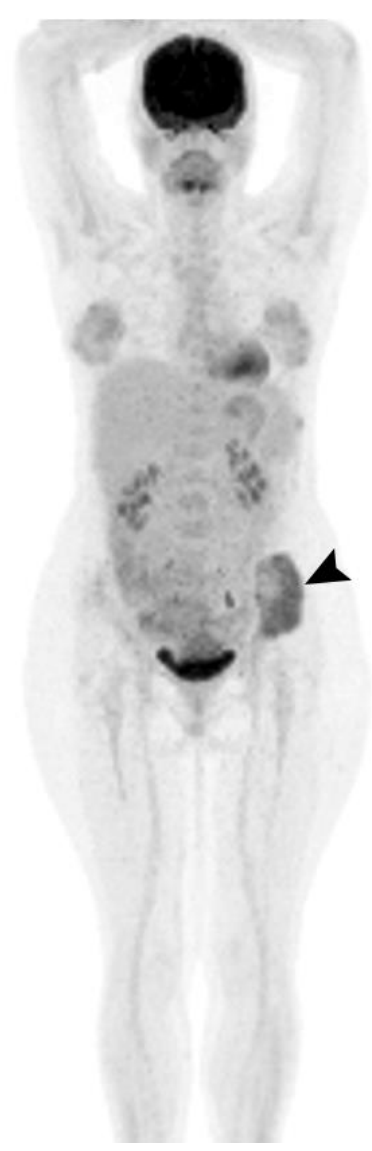

Fig. 4. PET/CT.

Maximum intensity projection images for initial staging showing pathological uptake of FDG in the tumor involving the left ilium (arrowhead).

Рис. 4. ПЭТ/Кт.

Изображение в максимальной интенсивной проекции в начальной стадии демонстрирует патологическое

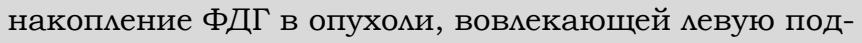
вздошную кость (головка стрелки).

Fig. 4 (Рис. 4) 
are currently limited [3].

Pregnant patients diagnosed with symptommatic MM need prompt therapy. Immunomodulatory drugs such as thalidomide and lenalidomide may induce marked teratogenicity, and should be avoided during the whole pregnancy period. Also, bortezomib cannot be recommended in pregnant patients, as there are few data about its safety.

Corticosteroids are the safest therapy of MM during pregnancy and can be used as a mono- therapy in patients with the mildly symptomatic disease until delivery. In rapidly progressive disease, intensive combination therapy is usually required. If this progressive disease is diagnosed in the first trimester, termination of pregnancy is recommended. If the patient has an extensive pelvic or vertebral bone disease, Cesarean section is preferred to avoid trauma resulting from a vaginal delivery [5].
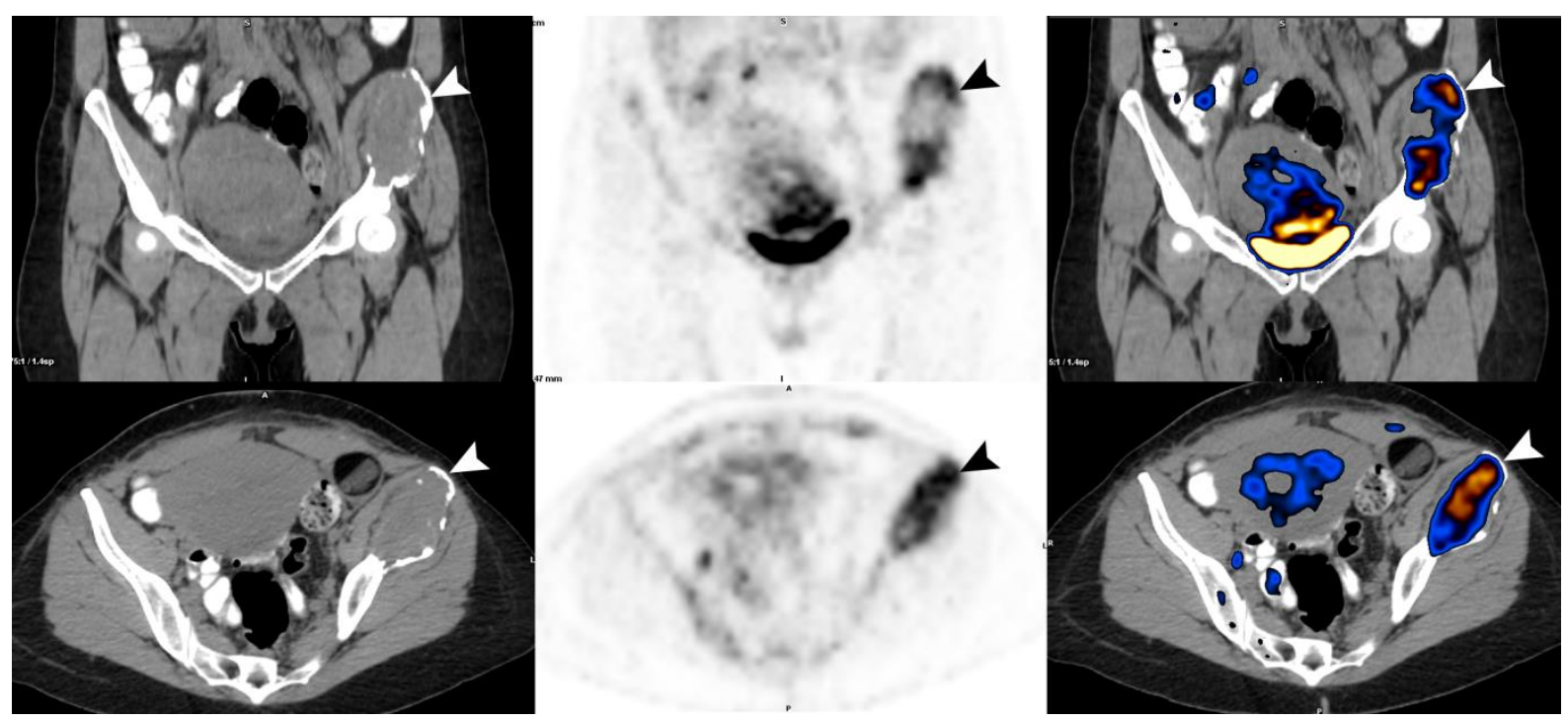

Fig. 5 (Рис. 5)

Fig. 5. PET/CT, coronal (upper level) and axial images (lower level). CT (first column), PET (second colUmn) and fused PET/CT (third column).

Pathological heterogeneous uptake in the plasma-cell tumor involving the left ilium with the cortex destruction (arrowhead).

Рис. 5. ПЭТ/КТ, изображения в корона^ьной (верхний ряА) и аксиаАьной (нижний ряА) п^оскости. КТ (первый столбик), пЭТ (второй столбик) и объеАиненный ПЭТ/КТ (третий столбик).

Патологическое гетерогенное накопление в опухоли, вовлекающей мевую подвздошную кость с кортикальным разрушением (головка стрелки).

\section{References:}

1. Lombardo E.M., Maito F.L.D.M., Heitz C. Solitary plasmacytoma of the jaws: therapeutical considerations and prognosis based on a case reports systematic survey. Braz J Otorhinolaryngol. 2018; 84 (6): 790-798.

2. Rajkumar S.V. Diagnosis and management of solitary plasmacytoma of bone. Post TW, ed. UpToDate. Waltham, MA: UpToDate Inc. https://www. uptodate.com (Accessed on Aug 09, 2018.).

3. Jurczyszyn A, Olszewska-Szopa M, Vesole AS, et al. Multiple
Myeloma in pregnant women - a Review of the literature and a Case Series. Clin Lymphoma Myeloma Leuk. 2016; 16 (3): e3945 .

4. Ghatak S., Dutta M., Kundu I., et al. Primary solitary extramedullary plasmacytoma involving the true vocal cords in a pregnant woman. Tumori. 2013; 99 (1): e14-8.

5. Mahmoud H.K., Samra M.A., Fathy G.M. Hematologic malignancies during pregnancy: A review. J Adv Res. 2016; 7 (4): 589-96. 